\title{
POLITICAL LANGUAGE TRANSFORMATION IN DIFFERENT TYPES OF POLITICAL REGIME
}

\section{Diachenko O. V.}

\section{INTRODUCTION}

In the modern political process and political activity, such political situations appear when manipulative techniques are used by the subjects of political life. Communication technologies in the modern practice of political management are intensively used to form perception models of sociopolitical reality by the society, as well as the mass behavior models designed to maintain the stability of the existing political regimes and achieve political management subject purposes. Appropriate techniques and means of linguistic-manipulative influence differ in their composition and forms of manifestation in different political processes. At different levels of the political process, a various set of linguistic-manipulative influence is used to achieve goals and introduce their political will into the public consciousness. There are many different factors that affect this. An important factor is one or another type of political regime according to which the strategy and influence tactics of this type are defined.

The effectiveness of the state political system is largely determined by the successful formation of relevant public perceptions of the national political system, national leaders or the political elite, state government institutions, etc. In addition, the manifestations of the population's behavioral reactions to various political events, both within the country and abroad, largely affect the stability of a particular type of political regime.

Political language possesses specific properties when applied within the framework of communication. According to N. Fairclough "the communication purpose in this case is sense, development or change of imperious relations, and the factors - actors of external character (political leaders, influence groups, etc.). Under these conditions, the speech effect is quite expressed. This effect is usually the result of a certain ideology. The latter is not only a modern alternative application of material impact or violence" ${ }^{1}$. Regarding the author's position of this paper, it is different. On the contrary, "ideology can support the use of violence in any form: from intellectual, spiritual or moral to physical” 2 .

1 Щербинин А. (1999) «С картинки в твоем букваре» или Аз, Веди, Глагол, Мыслете и Живете тоталитарной индоктринации. Полис, 1, 116-136.

${ }^{2}$ Ibid. 
Scientists M. Hrachov, H. Pocheptsov, P. Serio and others consider the political language as a relevant subsystem of the common national language, which performs the communicative function of the political direction. Namely, it carries out propaganda or introduces any ideas, exercises an emotional influence on the society and provokes a person to commit any political actions, etc. $^{3,4,5}$. In particular, P. Serio draws attention to the functions of the political language and notes that the main thing is "verbal support of the struggle for power" ${ }^{\circ}$.

In our view "political language is a reflection of political reality and, at the same time, a means of its formation, since it sometimes decides the fate of laws, politicians and parties. The political phenomenon is transformed into something sensible and accessible for discussion, expressed in words, so the basic concepts of political language, political formulas and clichés largely determine the way of perceiving political reality. The political process develops together with the language, relies on the language, and uses the language itself" ${ }^{\text {? }}$.

\section{Features of the political language of a totalitarian model of political communication}

Analyzing the interrelationship between the political process and political language, $\mathrm{H}$. Pocheptsov notes "solid scientific literature describing the relationship between political realities and their reflection in the language makes it possible to speak of the existing correlation of these two phenomena: the political process and the political language”. According to the scientist "the practice shows that the dissemination control of information of political nature is an important element in determining the type of political regime: under authoritarianism and totalitarianism, information processes are under strict control, while a democratic regime implies that political information is widely and freely distributed between various members of the society" ${ }^{8}$.

In the case of a democratic communication model, it should be based on political or social dialogue between those who govern and the governed. It is this element of communication interaction that enables the exchange of accurate and complete information that is uniform and reliable in relation to real political events and situations. It is this approach that corresponds to the generally accepted cultural and civilizational values of modern society and reflects the rights and freedoms of fundamental nature in the personality

\footnotetext{
${ }^{3}$ Грачев М. (1996) Актуальные проблемы политической науки. М.,188.

${ }^{4}$ Почепцов О. (1987) Коммуникативные аспекты семантики. Киев, 129.

${ }_{5}^{5}$ Серио П. (1999) Как читают тексты во Франции. Квадратура смысла. М., 12-53.

${ }^{6}$ Ibid.

${ }^{7}$ Дяченко О. (2016) Особливості мовно-маніпулятивного впливу за різних типів політичного режиму. Актуальні проблеми політики. Одеса, 58, 29-40.

${ }^{8}$ Серио П. (1999) Как читают тексты во Франции. Квадратура смысла. М., 12-53.
} 
development. The mutual exchange of information, which is important in political life, is based on these principles. With regard to the Soviet era, there were clear traditional rules of political communication - "all the communicants knew who, what, when, and in what form they should talk" .

In continuing this problem, it is worth paying attention to the so-called public ritual communication, which was a characteristic feature of the Soviet era. O. Baranov's statement that "the main task of public ritual communication is to fix its adherence to the rules for confirming its social role" ${ }^{\# 10}$ is correct in this regard. And here the question arises: is there such a form of communication in the modern political process”? According to Ye. Zemska's belief "modern political communication is sometimes not less ritual than in Soviet times, but now the ritual rules and roles of communicants have changed. A modern ritual is the fulfillment of the public defender roles, a human rights advocate, a patriot, a centrist, etc. by the politician”11. M. Hrachov, the researcher who has repeatedly cited, has the same viewpoint pointing out that "it is also peculiar to the democratic model of communication, especially for political discourse, where the primacy of values appears to be taken over facts, the predominance of influence and evaluation over information, emotional over rational" ${ }^{12}$. Such conditions are favorable ground for the application of various language manipulations.

For the modern stage, political language is characterized by "semantic uncertainty (politicians often prefer to express their opinions in the most general way possible, using words of extended or vague semantics); phantom (many signs of a political language do not have a real subject); irrationality (attention to the subconscious); esotericism (the real meaning of many political expressions are understood only by the elected); theatricality"13. At first glance, the above features "contradict the main purpose of communication of conveying certain information to the addressee"14. However, according to the article's author: "almost each of these properties is capable of serving the manipulative strategies of the speaker: uncertainty and phantomity allow veiling the true meaning of the expression, to get away from a specific answer; irrationality and theatricality increase the impact on the listener; esotericism focuses the audience, divides everyone into the initiates and the uninitiated" ${ }^{15}$. But it should be noted that

9 Дяченко О. (2016) Особливості мовно-маніпулятивного впливу за різних типів політичного режиму. Актуальні проблеми політики. Одеса, 58, 29-40.

${ }_{10}^{10}$ Баранов А. (2001) Введение в прикладную лингвистику. М., 360.

11 Земская Е. (1996) Клише новояза и цитация в языке постсоветского общества. Вопросы языкознания, 3, 23-31.

${ }^{12}$ Грачев М. (1996) Актуальные проблемы политической науки. М.,188.

13 Дяченко О. (2016) Особливості мовно-маніпулятивного впливу за різних типів політичного режиму. Актуальні проблеми політики. Одеса, 58, 29-40.

${ }^{14}$ Ibid, 29-40.

${ }^{15}$ Ibid. 
in the Soviet era, the mass media were not free and therefore, political speech obtained propaganda and agitation nature.

In this way, the totalitarian model of political communication is characterized by the relevant take over the public consciousness and instills a comprehensive political ideology, the task of which is the establishment of "absolute truth" and the impossibility of any other options and interpretations of socially significant events. It should be noted that it leads "to an attempt to destroy the freedom of personality and society, political, cultural, religious and linguistic freedom. The main features of totalitarian ideology include: teleological (purposeful) orientation in views on social development, which forms an attractive happy image of the future, eliminates everyday difficulties from the public consciousness; paternalistic character (protection, paternal attitude of the leaders to the people, gives a favorable ground for the manipulation of mass social consciousness" 16 .

With regard to the characteristics of the political language of the totalitarian model of political communication, it is possible to distinguish "a high degree of cliché, euphemism, violation of the fundamental communication postulates used for the purpose of linguistic manipulation, ritualized use of language, desemantization of not only of individual words but also of large discourse segments" ${ }^{17}$. This type of communication is also characterized by the polarization of "friend-or-foe" political rhetoric, which has an influence on the thinking formation at the social level, which confirms the thesis about the interrelation of political language and world view. G. Orwell made a reference to it believing that "control over language, through the use of words in a society, will determine the limits of the permissible mental process" ${ }^{18}$.

It should be noted that the educational, pedagogical component, which directly affects the corresponding model formation of political communication, in particular, in the framework of totalitarianism. Here, the point is about the distinction between education and propaganda, since language is a means and tool of education. C. Becker drawn attention to this believing that "the preaching of what we believe in is education and preaching of what we do not believe in is propaganda" ${ }^{19}$. Political discourse in a totalitarian communication model involves two essential language characteristics: it, in this case, acts as a means of propaganda and, at the same time, an education tool. This makes it possible to work in promoting education component

${ }^{16}$ Дяченко О. (2016) Особливості мовно-маніпулятивного впливу за різних типів політичного режиму. Актуальні проблеми політики. Одеса, 58, 29-40.

17 Земская Е. (1996) Клише новояза и цитация в языке постсоветского общества. Вопросы языкознания, 3, 23-31.

${ }^{18}$ Оруэлл Д. (2013) Роман. Скотный Двор. Сказка-аллегория. М., 412.

${ }^{19}$ Беккер К. (2004) Словарь технической реальности: Культурная интеллигенция и социальный контроль. М., 65. 
propaganda. A. Shcherbinin notes in this regard that "primer for adults (literacy elimination) and primer for children (literacy education) form the students' class position. Such primer can be rightly called the shortest course of the AUCP (All-Union Communist Party (of the Bolsheviks)) ${ }^{20}$.

The main problem in this model is that, in such a society, the people understand that the dominant ideology does not reflect reality, but no one is able to change this situation. The cultural-political manipulation can create such a situation using the verbal component. In such models, there can be no full-fledged official opposition force that could create appropriate protest political discourse. In order not to become the cause of conflicts, the authority changes the political language perspective and, for example, begins to use a large number of euphemisms.

The analysis of current political processes in the world makes it possible to say that a totalitarian political regime is not an impossible thing in the future, and it poses a real threat to the fundamental foundations of the development of a civilized society. Increasingly, we see totalitarian political rhetoric and manifestations of certain features of totalitarian political language in the media.

According to the author "a political language in a totalitarian regime is characterized by: monologue of communication (unilateral influence on the addressee - society); lack of alternative sources of linguistic influence and feedback; clichéd and ritualized communicative behavior; absolutization of the political language written form (spontaneous speech disappears, oral public speeches must first be spelt out and verified); anonymity of individual discourses, the pattern of expression of ideas and opinions" ${ }^{21}$.

\section{Features of the democratic model of political communication language}

It is considered that "unlike the totalitarian regime, a dialogue between those who govern and the governed, based on a democratic and tolerant model of political communication, which provides for an equal exchange of accurate, complete and verified information about political phenomena and processes that are combined with basic civilized and cultural values of a given society, fundamental rights and freedoms of the individual”. In addition, it should be noted that "in a democratic society, the essence of political communication changes: every citizen has the right to participate in government, as well as the right to choose positions, to publicly evaluate the actions of the authorities"22.

${ }^{20}$ Щербинин А. (1999) «С картинки в твоем букваре» или Аз, Веди, Глагол, Мыслете и Живете тоталитарной индоктринации. Полис, 1, 116-136.

${ }^{21}$ Дяченко О. (2016) Особливості мовно-маніпулятивного впливу за різних типів політичного режиму. Актуальні проблеми політики. Одеса, 58, 29-40.

${ }^{22}$ Ibid. 
A variety of ideas, views and opinions inform the society and allow people to understand something in the analysis of political situations. Such freedom, which is possible for a person in a democratic society, in a democratic political regime, the society is provided with the opportunity to develop, and the ability to freely express one's thoughts and assessments regarding the current political process. This, in turn, shapes different views, political ideas and trends, and new socio-political movements and parties emerge, is a manifestation of political pluralism. All this diversity is a prerequisite for a widely recognized political discourse to be divided into state, party and group. The subjects of state political discourse are the representatives of the state authority at all government levels, and they represent the "official political communication".

The next type of discourse - party, includes members of political parties regarding their party activities and the language of party documents. The purpose of a particular discourse is the formation of public opinion, its mobilization and direction in support of the political movement.

It should be emphasized that "the emergence of a multi-segmental political discourse is possible due to democratic transformations in the society. At the modern stage, the political and media segment is changing most dynamically. The mass media is an influential subject of politics that shapes public opinion, public consciousness, organizes and exerts influence on public behavior" ${ }^{23}$. And here it should be emphasized that the media, which do not have such official powers, which are in other branches of government, but the ability to influence society, public opinion, political events - is even greater. And this is possible in a democratic model of political communication.

Now society has opportunities to provide up-to-date information that directly affects mass, group and individual consciousness and political behavior. The level of activity, independence and self-dependence of the media is an indicator of the type of political regime, the direction of the authorities' activity, and therefore political communication in the media has its own functions. They act as agents for the formation of political culture, identify political opinions and benchmarks, provide platforms for real societal participation in the political process, perform integration activities, and encourage society to acquire the new priority of political values and ideas and so on. There is an interesting fact that the media in the democratic regime also perform a controlling function which "integrates interests around some doctrines and formulates the party credos; it is through the press that parties engage in dialogue with each other without meeting; agree without contacting. When, however, it happens that a large number of print editions begin to act in one direction, their influence for a long time

${ }^{23}$ Дяченко О. (2016) Особливості мовно-маніпулятивного впливу за різних типів політичного режиму. Актуальні проблеми політики. Одеса, 58, 29-40. 
becomes prevailing, and public opinion, which is processed all the time on the one hand, as a result, is influenced" ${ }^{24}$.

According to $\mathrm{H}$. Khazarehova, today "the use of political language during election campaigns applying the techniques and methods of advertising business as a communicative influence is of great importance. The most striking example of the merging of political and advertising technologies in shaping political language is the election postcard" 25 . As the scientist notes "losing the informative nature in exchange for influence, the postcard, instead of information about the candidate, gives a simplified idea of the person to be selected. The political postcard demonstrates the presence of all trade advertising components: trademark, a slogan, difficult situation, product representation, a facilitated situation and motivational component" ${ }^{26}$.

The name and image of the politician is a trademark, the slogan is the appropriate political motto. "The difficult situation looks like the existing unsatisfactory state of affairs, the facilitated situation is a promise that the situation will improve for the better with this candidate's accession to power, and the motivational component is an explanation of why this will happen ${ }^{27}$.

According to the political discourse principles, the political name includes the names of the most popular politicians, parties or movements, for example, the names of the political party "Freedom", "People's Front", "Opposition Bloc" -is already a suitable political brand. The democratic model of political communication has a wide variety of language tools. This gives broad opportunities for the influence text area. This freedom of choice of tools ensures that voters have political texts accessible and understandable. For example, during the 2010 election campaign, politicians used such political slogans that were simple enough and understandable for the voters of the time; "We will raise the economy - we will raise the country", "Professionals should lead the country" (S. Tihipko), "They are destroying, she works", "she will win, she is Ukraine" (Yu. Tymoshenko), "Ukraine for the people", "I will hear everyone" and others.

The educational and pedagogical direction of the democratic model of political communication must also be developed. Attention should be paid to the methodological part, the creation of various new textbooks, various author's programs, special courses, which provides freedom of choice.

In other word, such a democratic model of political communication is characterized by the following features: "communication dialogue"; pluralization of people's communicative behavior (language strategies vary depending on the position of the communicants, the communication type, the

\footnotetext{
${ }^{24}$ Токвиль А. де (1992) Демократия в Америке. М., 560.

${ }^{25}$ Фуко М. (1997) История безумия в классическую епоху. СПб., 576.

${ }^{26}$ Ibid.

${ }^{27}$ Ibid.
} 
communication participants' personal characteristics); development of public speeches (especially its oral varieties: spontaneous speeches, public real-time communication - interviews, conversations, talk shows, public discussions, political debates); communication personification (uniqueness of expression and expression of similar ideas and thoughts by different people)"28. To this, one could also add: the composition expansion of the political communication recipients significantly increases the role of interactive communication and so on. This applies to the self-structuralization of relevant discourse practices that use the media.

When it comes to post-communist countries, one must take into account the corresponding hermetic privacy that reflects the specific "opacity" zones that have emerged in society. In such societies, the language used in newspapers, clichés and stereotypes that were present there became popular in the transitional phases and most strongly expressed the articulation of an unstructured underdeveloped society with non-standard components. This is covert aggression, a large number of metaphors in political rhetoric. The presence of aggression characterizes this model from the perspectives of intimidation, violence, coercion peculiar to the totalitarian model. The metaphors show lack of responsibility and "non-discursiveness" of public dialogue. It is the presence of a large number of metaphors that reflects the subconscious in the extra linguistic field. The result is the emergence of affects that substitute for an adequate discursive practice. There is a situation when the media create some kind of infrastructure of the public sphere and therefore, discursive practices disappear. As a result, instead of shaping people's foresight through reasoning and public opinion, there is a multiplication of fuzzy paleo-symbolic language with different stereotypes and specific party (political) jargon. Although it is precisely in this that the manipulative nature of the public word, which is present in the totalitarian model of political communication, is manifested. In Soviet times, these types of rationality were formed, which, together with the value priorities that had been formed earlier under the old regime, changed political discourse to a state of "clinical" monologism. Important socio-economic developments and political decisions have become propaganda tools.

Later, in the post-communist period, the phenomenon of democratic governance simulation formed. It reflected in the fact that a person who does not possess any means of exercising power is responsible for the efficiency of the state. The practice of "double morality", which is characteristic of the social consciousness of the Soviet model and the "internal censorship" system, which is one of the elements of such consciousness, is spreading.

${ }^{28}$ Дяченко О. (2016) Особливості мовно-маніпулятивного впливу за різних типів політичного режиму. Актуальні проблеми політики. Одеса, 58, 29-40. 
Therefore, it is quite difficult to talk about political discourse in the socalled "transition period". The social dialogue in question in post-communist countries has been largely distorted by totalitarian values and traditions of totalitarian political language. This significantly complicates the process of transition to democratic political discourse, which is one of the sources of legitimacy of the institutions of a developed civil society.

In post-communist countries, a form of linguistic behavior, which replaces public dialogue with relevant semantic articulations, is widespread. They act as some aggregates of violence, coercion, some specific conventions. The function of discourse as a vehicle, which combines the rational traits of the individual and the collective in society, does not work here. In such circumstances, the former needs, values and dreams are no longer amenable to understanding and defining in political discursive practice, and therefore, their meaningful content is in the field of non-political reality.

The approach initiated by M. Foucault in his work "The History of Madness in the Classical Era" may be quite productive for analyzing the practice of political discourse in post-communist countries. The main concept in the work was the term "deviation", and the term "language" acts as an element of madness. Foucault states that "if we introduce democratic discourse as a dialogical ethic, then rejection will always indicate a violation of such ethics rules, a potential opportunity to fall into an affective state, which can be expressed on a linguistic level by irony, silence, stereotyping, metaphorical chatter, hidden or open threat" ${ }^{29}$. As noted above, public dialogue in post-communist countries is being replaced by any form of tyranny's affects. Accordingly, it is very difficult to speak of a democratic model of political communication, because the formation of political discourse in such circumstances will be an unstable and moving process. Following the events of 1917, when sociocide was allowed, the final destruction of civil society institutions occurred and the basis of "dialogic" linguistic ethics, which was replaced by loyalty ritual, disappeared.

Political discourse restoration was made possible by the "education restructuring" and not by the development of civil society institutions. This was a consequence of the repressive system of human entry into social life. This process was characterized by manipulative traits and ensured that a person was constantly in the propaganda field, which was filled with compulsive impulse. When this field began to crack, many contradictions arose within the framework of public political dialogue. Today, there is mass involvement in the introduction of political rhetoric of people possessing different experience, occupation, education and, above all, they lack economic freedom. And this, in turn, makes them incapable of understanding special

\footnotetext{
${ }^{29}$ Фуко М. (1997) История безумия в классическую епоху. СПб., 576.
} 
terminology in the fields of economics, politics, philosophy, etc. That is, such a speech activity spurt is the result of the ideology of equality and was characteristic of societies with the class illusion, and then substantial proletariat advantages.

Some paradoxical situation in which the lack of the institutional traditions of civil society does not form democratic political discourse and hampers such society democratic institutions creation arises.

The key element in the politics of the post-communist period is the political language factor, discourse, political rhetoric. This is the rhetoric of a good future that has to be legitimized in political discourse and real social forms. That is, through political language, a reciprocal feeling is formed that the whole society influences progressive processes (market, democracy, freedom, reforms). However, society did not understand that this feeling does not guarantee this development. That is, from the experience of other countries that have already gone this route, it can be stated that progressive development depends on how much it is possible to master the current situation at the level of political discourse, because practically, everyone involved in global changes in society and its basic principles of life, should perform transition from the tacit support of the authorities to active political discourse. And this is one of the main elements from which politics is created.

Moreover, the priorities change in the political values perspective happens not only with political scientists, but this change must take place in the minds of the whole society. It is a broad involvement of the public in active political discourse, which ensures, for example, a high level of activity in elections or in the activities of power structures. Today, already quite broad masses, both at the conscious and the unconscious levels, have acquired the "Zoon politcon" qualities. These are the qualities that make it possible to understand the importance of political events and how these events affect everyday social life. And most importantly, these qualities make it possible to understand the relationship between the perspectives of one's life and the state development directions. In this process of entering into the political process communicative competence is formed and the person already at a conscious level makes any political choice and carry out, accordingly, socially important actions. That is, in the post-communist periods, it is imperative to learn political language.

And the situation is the same today. The political processes that are taking place in Ukraine also require development in this direction, the importance of the political word is growing. And this significantly changes the attitude towards the politics, the political system, the society, and so on. A politician must be able to speak political rhetoric, political language, express own opinions in such a way that the society understands politics. Democratic political discourse requires the openness of previously hidden aspects which happens through the word. 
It is openness and publicity that lead to the politicization of social life. The word itself is an instrument of the enlightening role of democratic political discourse, which determines not only the limits of political thinking but also the reality of political action. The essential content of democratic political discourse becomes understandable only when the word is not merely a quantity of facts or evidence. Linguistic political discourse also contains desires, dreams, some different facts and different forms of human life. Language (speech), especially political, always contains our interpretations of the outside world and evaluative semantic forms regarding real or possible political events. Political ideas and power relations are also captured with the help of language, so democratic political discourse defines various possible forms of political practice.

The degradation of a political regime and the decline of political ideology occur by the degradation of language. Old speech cannot disappear at the same time in any mechanical way. This happens discursively. The key elements of the political language of the Soviet era today are inappropriate in modern society that is open and progressive. It is the language that determines the claims of politicians and at the same time defines one's participation horizons in political discourse.

So, in the opinion of the author, the following features are characteristic of the political language of the modern period: "process intensification of borrowing foreign words and the rather strong slang influence and everyday speech, as well as general stylistic decline in modern political language”. It can be said about "increased aggressiveness of modern political language, active use of confrontational strategies and tactics of linguistic behavior (threats, neglect, discredit, falsehood, labeling, insults, etc.)" ${ }^{30}$. For example, we see some politicians and statesmen express offensive expressions in the political rhetoric today: "populists”, “speculators”, "bastards”.

\section{CONCLUSIONS}

Political language reflects not only the real state of affairs in Ukraine but also its perception in the national consciousness. Reality and its awareness in the social mentality do not always coincide.

It should be agreed with N. Efteni's position who believes that "political manipulation acts as one of the conditions for stable existence of political regimes and allows controlling the personality and his consciousness. Political manipulation tools need to be continually developed and refined as they help the political regimes function steadily. Political manipulation must be planned and organized, as it may entail potential risks to the development of society as a whole. Furthermore, in the author's opinion "it is necessary to

${ }^{30}$ Дяченко О. (2016) Особливості мовно-маніпулятивного впливу за різних типів політичного режиму. Актуальні проблеми політики. Одеса, 58, 29-40. 
actively involve the mass media that effectively disseminates the necessary information and renders the greatest impact on public consciousness" ${ }^{31}$. It can be defined that "cultural and manipulative technologies are inherent in any political regime”,32, although they have their differences and characteristic features.

Thus, in our opinion, the following are inherent for a political language in a democratic mode: dialogue (instead of a monologue under a totalitarian regime) the presence of feedback from the addresser and the addressee of the information; pluralization of communicants' communicative behavior; extensive use of public speeches; increment in the proportion of spontaneous performances; individualization and promotion of subjectivity of the design of thoughts and ideas.

\section{SUMMARY}

This monograph section focuses on the transformation of political language in different types of political regime.

A comprehensive analysis of the political language of the totalitarian model of political communication in Soviet times, in the "transition period" and the democratic model of political communication is performed.

The paper shows what the political communications of various political regimes, in Ukraine, have in common and the exact differences. The influence of political language on public consciousness is investigated.

Attention is focused on the fact that political language reflects not only the real state of affairs in Ukraine but also its perception in the national consciousness.

Thus, the key elements of the political language of the Soviet era today are unsuitable for modern society that is open and progressive. It is the language, that determines the claims of the politicians and at the same time defines own participation horizons in political discourse.

${ }^{31}$ Єфтєні Н. (2015) Політичне маніпулювання: особливості застосування. Актуальні проблеми політики, 56, 234-241.

32 Дяченко О. (2016) Особливості мовно-маніпулятивного впливу за різних типів політичного режиму. Актуальні проблеми політики. Одеса, 58, 29-40. 


\section{REFERENCES}

1. Баранов А. (2001) Введение в прикладную лингвистику. М., 360.

2. Беккер К. (2004) Словарь технической реальности: Культурная интеллигенция и социальный контроль. М., 65.

3. Грачев М. (1996) Актуальные проблемы политической науки. M., 188.

4. Дяченко О. (2016) Особливості мовно-маніпулятивного впливу за різних типів політичного режиму. Актуальні проблеми політики. Одеса, 58, 29-40.

5. Єфтєні Н. (2015) Політичне маніпулювання: особливості застосування. Актуальні проблеми політики, 56, 234-241.

6. Земская Е. (1996) Клише новояза и цитация в языке постсоветского общества. Вопросы языкознания, 3, 23-31.

7. Оруэлл Д. (2013) Роман. Скотный Двор. Сказка-аллегория. M., 412.

8. Почепцов О. (1987) Коммуникативные аспекты семантики. Киев, 129.

9. Серио П. (1999) Как читают тексты во Франции. Квадратура смысла. М., 12-53.

10. Токвиль А. де (1992) Демократия в Америке. М., 560.

11. Фуко М. (1997) История безумия в классическую епоху. СПб., 576.

12. Щербинин А. (1999) «С картинки в твоем букваре» или Аз, Веди, Глагол, Мыслете и Живете тоталитарной индоктринации. Полис, 1, 116-136.

13. Fairclough N. (1989) Language and Power. N.Y., 259.

Information about the author: Diachenko O. V.,

Candidate of Political Sciences, Senior Lecturer at the Department of Political Science, Odessa I. I. Mechnikov National University 2, Dvorianska str., Odessa, 65082, Ukraine 